\title{
Article \\ Structural Analysis of Five Historical Minarets in Bitlis (Turkey)
}

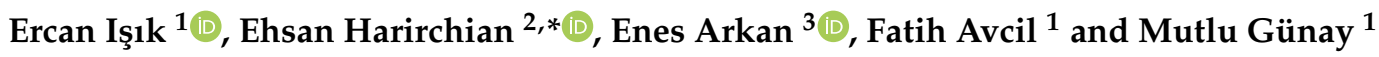 \\ 1 Department of Civil Engineering, Bitlis Eren University, Bitlis 13100, Turkey; eisik@beu.edu.tr (E.I.); \\ favcil@beu.edu.tr (F.A.); mutlugunay@gmail.com (M.G.) \\ 2 Institute of Structural Mechanics (ISM), Bauhaus-Universität Weimar, 99423 Weimar, Germany \\ 3 Department of Architecture, Bitlis Eren University, Bitlis 13100, Turkey; earkan@beu.edu.tr \\ * Correspondence: ehsan.harirchian@uni-weimar.de
}

Citation: Işık, E.; Harirchian, E.; Arkan, E.; Avcil, F.; Günay, M.

Structural Analysis of Five Historical Minarets in Bitlis (Turkey). Buildings 2022, 12, 159. https://doi.org/ 10.3390 /buildings12020159

Academic Editor: Chiara Bedon

Received: 12 January 2022

Accepted: 28 January 2022

Published: 2 February 2022

Publisher's Note: MDPI stays neutral with regard to jurisdictional claims in published maps and institutional affiliations.

Copyright: (C) 2022 by the authors. Licensee MDPI, Basel, Switzerland. This article is an open access article distributed under the terms and conditions of the Creative Commons Attribution (CC BY) license (https:// creativecommons.org/licenses/by/ $4.0 /)$.

\begin{abstract}
Bitlis has hosted many civilizations and is located in Turkey's significant strategic transit corridor. Many historical structures belong to different cultures in the city. The structural analysis of five minarets mentioned in folk songs and the brand value of Bitlis city in terms of historical buildings is the subject of this study. These minarets are precious because they witness important events in Bitlis city. Non-destructive test methods determined the material properties of the Bitlis stone used in constructing minarets. Within the scope of the study, detailed information about each minaret was given, and on-site measurements determined its dimensions and current structural conditions. For each minaret, its seismic behavior has been selected by using the vertical and horizontal design spectrum in the recent earthquake code of Turkey. Historical masonry minarets were modeled using the finite element method. In addition to stress distribution in the minarets under different loading conditions, period and displacement results are also investigated.
\end{abstract}

Keywords: historical heritage; finite element analysis; damage assessment; minaret

\section{Introduction}

Studies on historical artifacts have an important place in preserving their historical and cultural heritage and transferring it to the next generations. Such works contain information about the social life of the societies of the period and construction technologies. The fact that they have survived over time is an indication that such structures receive outstanding engineering services without any high-level technology [1-3]. The protection of cultural heritage and its safe transfer to the future are among essential engineering research and implementation subjects of the 21st century. Since this vital subject meets on common ground with fields of science such as engineering, architecture, art history, and archeology, it also attracts the attention of interdisciplinary working groups, which have gained importance in recent years [4-8].

Historical buildings are invaluable cultural assets that strongly connect the past and the future. Historical buildings are also an indicator of societies' engineering background, artistic understanding, and economic status. The Van Lake basin has hosted many civilizations in the historical process such as Hurrian, Urartian, Med, Persian, Sassanid, Seljuk, and Ottoman civilizations. Since the basin is a very old residential area, it has carried the historical structures and cultural values left behind by many civilizations until today. There are many historical buildings in the basin that were built in very old times and are still in use after restoration works. Bitlis is one of the centers in this basin that has cradled many civilizations. Lake Van basin is also a region that causes great loss of life and properties after destructive earthquakes.

Investigation of earthquake resistance of buildings, determining and examining earthquake safety, and the parameters affecting the safety of the buildings have increased its importance in recent years. For these reasons, determining earthquake behavior and the safety of structures is one of the most basic study fields of earthquake engineering. From 
the results of previous earthquakes, it can be observed that heavy damage and destruction in structures are relatively high depending on the level of development. However, it is crucial to distinguish and separately analyze the parameters that share in the formation of these damages and destructions. For this reason, when observing the behavior of structures under the effects of earthquakes, knowing the factors that will affect the earthquake resistance of structures attains particular importance. Studies and research on historical artifacts, which are a part of cultural heritage, both in our country and in different parts of the world are becoming more common day by day [9-12]. Some of these research studies include Bajrakli Mosque (Western Kosovo) [13], SS. Rosario Church Bell Tower [14], St. Mary of Carmel Church [15], Ben Ezra Synagogue [16], Athena Temple [17], Madre Santa Maria del Borgo Church [18], and Gazi Hasan Pasha mosque [19]. These studies are studies on monumental structures built in a masonry style. These studies can also be considered as case studies for the modelling and strengthening of monumental masonry structures with the finite element method, determining the material properties used, and determining their seismic behaviour using different analysis methods.

Minarets have an important place among historical monumental structures. Since these structures, which are symbols of faith, were built differently in different civilizations, they provide information about the construction and construction technologies of that period. Although minarets are built in different systems, historical minarets are commonly encountered as masonry structures. Generally, they were built by local cut stones and minaret masters of the region. There are many studies on minarets, which are an integral part of our historical assets. In studies on such minarets, the behavior under the influence of earthquakes has been examined in general. Çaktı et al. (2013) [20], by giving information about the damage to the minarets in the 2011 Van earthquake, provided the results of the study for forty-one new and historical minarets in Istanbul. In the study, the earthquake behavior of the Edirnekapı Mimrimah Sultan Mosque minaret has been specifically examined. In addition, information about earthquake recording and monitoring systems used in minarets is given. Işık and Antep (2018) [21] determined the seismic behavior of the minaret of the historical Kadı Mahmut Mosque in Ahlat district in terms of different load combinations, using the design spectra specified in the Turkish Seismic Design Code-2007 (TSDC-2007) [22]. In the study carried out by Kılıç et al. (2020) [23], the dynamic behavior of the Kirklareli Hizırbey Mosque Minaret was determined. In the study, analyses were investigated by the methods given in both TSDC-2007 and the Turkish Building Earthquake Code (TBEC-2018) [24]. Ural and Çelik (2018) [25] attempted to determine earthquake behavior and dynamic analysis of masonry minarets with a single balcony. In this context, seven different minarets in Aksaray district were chosen as examples. The finite element method was used in the analysis of minarets. Mutlu and Şahin (2016) [26], on the other hand, investigated the earthquake behavior of the historical Ulu Mosque minaret in Bursa by using different modeling techniques. Dynamic analyses were performed in the time history using acceleration time curves. Bayraktar et al. (2013) [27] determined the dynamic properties of the minaret of the historical Sundura Mosque, for which renovation was carried out, using environmental vibration test methods after restoration. Günaydın (2018) [28], in his study, determined the dynamic characteristics of the minaret of the Trabzon İskender Pasha Mosque after restoration processes. These processes were carried out experimentally. Çarhoğlu et al. (2013) [29] analyzed the seismic behavior of the minarets of the Hagia Sophia Mosque, one of the most important mosques of our country, in their work. The time-history analysis method was used in this study. Uğurlu et al. (2017) [30] carried out structural analyses by modeling the Four-Legged Minaret, one of the important historical buildings of Diyarbakır. Oğuzmert (2002) [31], in his master's thesis, information was given about the structural analysis of masonry minarets built differently and the methods used in masonry structures. Döven et al. (2018) [32], in the study, determined the dynamic behavior of the Green Minaret in the city of Kütahya in the case of closed and open balconies and compared them. Güneş et al. (2021) [33] focused on the seismic assessment of a reconstructed ruined mosque built between 1807 and 1820. Ertek and 
Fahjan (2007) [34], in their study, provided information about the construction systems and technologies of the historical minarets of the Ottoman period, their classification, and how to model and analyze them. Çalık et al. (2017) [35] provided information on simplified natural frequency formulas for historical masonry minarets using experimental methods. Yetkin et al. in their study in 2021 [36] examined the damage to the minarets in Elazig city after the 6.8-magnitude earthquake that occurred in the Sivrice district of Elazig city on 24 January 2020. The sections where the damages occurred in the minarets examined were determined, and the reasons for the formation of these damages were evaluated.

Structural analyses of five minarets, which are the subject of the song Five Minarets in Bitlis written to describe the situation in the occupied city, were carried out using the horizontal and vertical design spectrum defined in the current Turkish Building Earthquake Code (TBEC-2018) and obtained using the Earthquake Hazard Maps Application of Turkey. The local name Bitlis stone was used in the construction of the minarets. This stone's material properties (modulus of elasticity and Poisson ratio) were obtained by using nondestructive test methods, and these values were used in the analyses. A survey study was conducted for each minaret, and finite element models of minarets were created. In this study, while giving detailed information about Five Minarets, their current situation is also stated based on observation. The safe transfer of these minarets to the next generations, which are of great value for Bitlis, is significant for preserving its historical and cultural heritage. The information obtained within the scope of this study will be an archive for such structures. For the first time, the modulus of elasticity and the Poison ratio were obtained for Bitlis stone. It is crucial to be the first and detailed study on Five Minarets, one of the brand structures of Bitlis city.

\section{Materials and Methods}

\subsection{Five Minarets}

This study is important in that it is the first study on the structural analysis of Five Minarets, which is one of the important cultural and historical advertising structures of Bitlis city. The most well known is the minaret of the Ulu Mosque of Five Minarets. This minaret was built after the mosque. The Ulu Mosque, to which the minaret belongs, is one of the oldest mosques in Bitlis. In addition to the Ulu Mosque in Bitlis, the Şerefiye Külliye, Dört Sandık Gökmeydan, Ayn'el Barit (Soğuk Pınar), Sultaniye, Meydan, Kızıl Mescit, Seyit İbrahim, Alemdar, Hacı Begiye, Kureyşi, and Memi Dede mosques are important historical places of worship of the city. The minarets, which are the subject of the song "Five Minarets in Bitlis", belong to the Ulu Mosque, Şerefiye Mosque, Meydan, and Gökmeydan mosques. It is estimated that the fifth minaret belonged to one of the Hatuniye, Kalealt1, or Kadiri mosques, and when it was destroyed, a new one was built in its place. The positions of Five Minarets are shown in Figure 1 and visuals are shown in Figure 2.

In general, minarets consist of the pulpit, the transition segment, the body, the balcony, the upper part of the body, the spire, and the end ornament from bottom to top. As an example, parts of the Ulu Mosque minaret are shown in Figure 3. The parts of the other four minarets are similar to the Ulu Mosque minaret. There is no difference in the parts of Five Minarets.

When the city of Bitlis is mentioned, the folk song "Five Minarets in Bitlis" comes to mind immediately. The story of this song is as follows. Bitlis, which was under Russian occupation for 5 months and 5 days and gained its freedom on 8 August 1916 took the appearance of a ruined city due to the fact that the city was destroyed during the occupation. A father and son, who fled from Bitlis during the war, returned to Bitlis after the withdrawal of the enemy and reached the foot of Dideban Mountain, where the city of Bitlis is visible. The father sends his son to the city to find out if somebody is alive in the city. After examining the city for a while, the son turns to his father and calls out from afar: "There is no trace of life in the city". When he said, "Only five minarets have survived", his father, hearing this, collapses and kneels down and calls his son to him with a lament: "Five Minarets in Bitlis, come back, son, come back, my heart is full of wounds, come back, son, 
come back". This lament, sung by the father, has survived to the present day as the subject of folk songs and poems. The folk song "Five Minarets in Bitlis" was composed in 1970 by Fatih Gündoğdu, who worked at Turkish Radio and Television (TRT)-Istanbul Radio. This song has become the advertisement words of Bitlis city over time [37-46].



Figure 1. (a) The location of the Bitlis city in Turkey. (b) The location of Five Minarets in Bitlis city. (c) The site plan of the Ulu Mosque and its minaret. (d) The site plan of the Şerefiye Külliye and its minaret. (e) The site plan of the Meydan Mosque and its minaret. (f) The site plan of the Kalealtı Mosque and its minaret. (g) Plan of Gökmeydan Mosque and Minaret. 

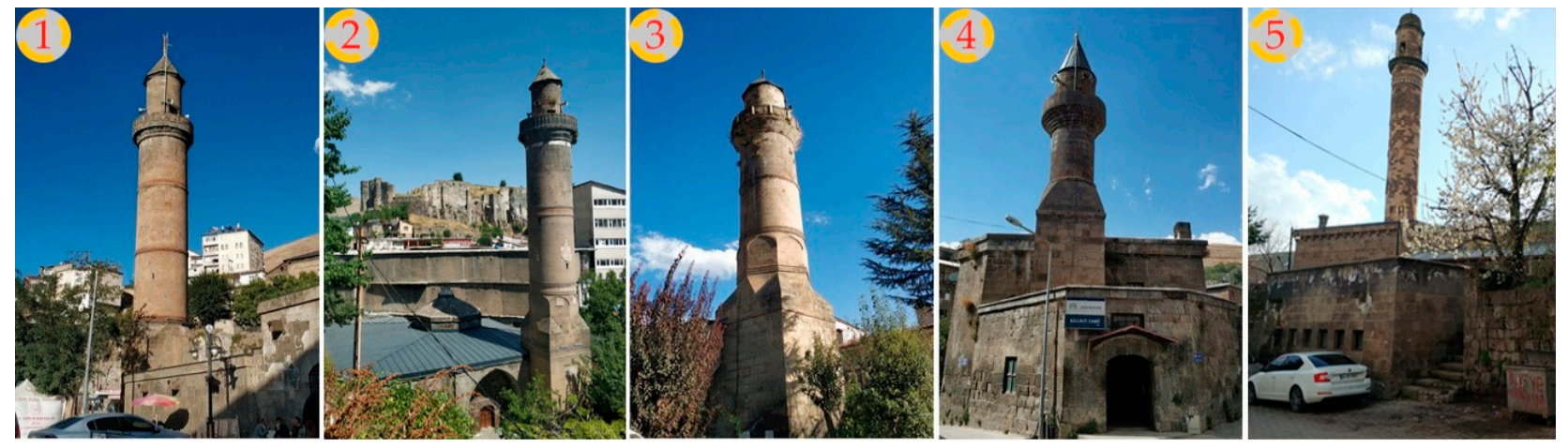

Figure 2. Visuals of Five Minarets: (1) Ulu Mosque Minaret, (2) Şerefiye Mosque Minaret, (3) Meydan Mosque Minaret, (4) Kalealtı Mosque Minaret, and (5) Gökmeydan Mosque Minaret.

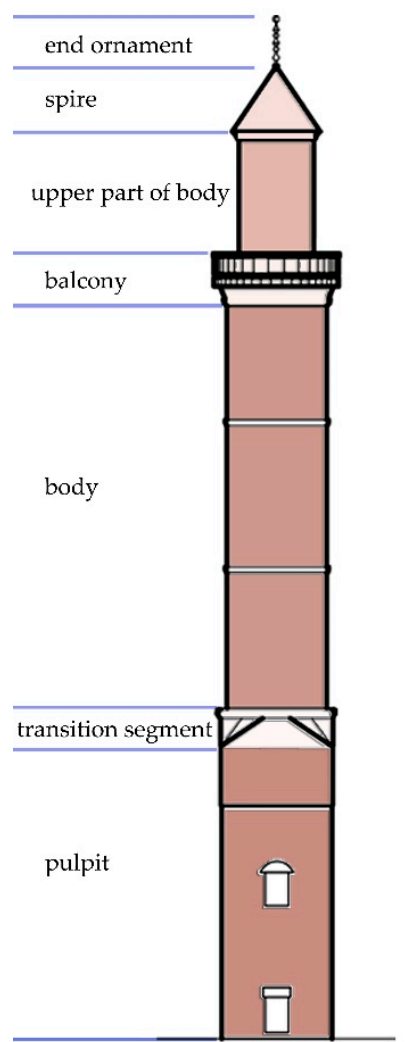

Figure 3. Parts of the minaret of the Ulu Mosque.

\subsection{Ulu Mosque and Minaret}

Although the exact date of construction of the Ulu Mosque in Gazibey district is not known, it is stated that the structure was one of the mosques destroyed by Byzantium in 928, as Şen reported from İbn'ül Esir in 2018. This means that the mosque was built in the city in the 7th or 8th century after the first Islamic conquests [44]. The mosque, together with the Bitlis Castle, is the oldest building in the city center of Bitlis.

There are three inscriptions on the construction/repair of the mosque, which are the most important historical documents among the immovable cultural assets. These are located on the upper part of the middle and western doors at the entrance to the sanctuary from the courtyard and the upper part of the minaret pulpit (boot). The inscriptions belong to the renovations and restorations of the mosque. The inscription dated 1150 on the middle door is an inscription belonging to the renovation of the building and corresponds to the reign of Dilmaçoğulları. The other renovation inscription dated 1651 corresponds to the period of the Serefhans under the rule of the Ottoman Empire. Ulu Mosque, which is one 
of the first examples of a rectangular horizontal plan mosque, also sets an example for the plan development of the Artuqid period [45-48].

The minaret is at the northwest part of the courtyard with the portico, which was unearthed as a result of the restoration works in 2012. There is an inscription on the construction of the minaret, dated 1492-1493, on the entrance door in the eastern direction [44,48]. Its construction date coincides with the period of Serefhans. The upper parts of the minaret, which has a square prism-shaped pulpit, were chamfered and a circular body was passed with a two-stage bracelet. The body is divided into three parts by two cornices. There is an inscription on the south face of the middle one of these partitions, which does not contain any ornamental elements. The transition to the balcony was made with a bracelet. The wall of the balcony is plain. The upper part and spire of the minaret were destroyed by a lightning strike, and these parts were repaired in an inaccurate manner. There is a door opening to the south in the plain upper part section of the minaret with a cylindrical body. The spire section was renovated in the form of an octagonal prism.

\subsection{Gökmeydan Mosque and Minaret}

It is written on the inscription on the east side of the Gökmeydan Mosque, which is located in the Taş District, that it was built in 1801. The southern part of the mosque, which was built on sloping topography, was designed as two floors. The building, in which the original function of the lower floor is used as a madrasa zawiya or khalwa and the upper floor as a place of worship, has a rectangular plan in the north-south direction.

The minaret was built to the west of the mosque, near the southwest corner. There is an inscription that also mentions Atatürk, dated 1924. It is the minaret with the most ornaments among the existing minarets. The square prism pulpit is entered through a door with a relieving arch in the southern part. The pulpit is divided into two with a cornice on the door. On the lower part of the south face, there is a circular inscription with floral motifs. Just above this, there is a relief decoration with lozenges. The part of the pulpit that connects to the bracelet on the body is built in the form of an inverted pendentive. The part of the pedestal that connects to the bracelet on the body is built in the form of an inverted pendentive. On the body part, an ornamental arrangement was preferred with motifs in the form of rosette-drop-rosette-triangle in four rows from bottom to top. In the lower part of the balcony, there is a row of ornaments made of white limestone in the form of lozenges, two cornices with ornaments in between, and a similar ornamentation series with a lozenge embossed from Bitlis stone. It has a metal railing balcony. The upper parts of the minaret section are octagonal prism, and there is a passage to the minaret on its four faces. There are four passages on four faces. The decorated eaves are covered with a stone dome $[44,46]$.

\subsection{Meydan(Çarşı) Mosque and Minaret}

Meydan Mosque was destroyed in the 1915 Russian occupation, and its minaret stood alone in the bazaar square to the south of Bitlis Castle until the beginning of the 2000s. Reconstruction studies were carried out by the relevant institutions in $2003[46,49]$. There is an entrance door on the east face of the square prism pulpit of the minaret, which was built adjacent to the northwest part of the mosque. Passing from square prism to octagonal transition segment is provided with triangulations. There are eight blind arches in the transition segment. In the transition to the cylindrical body with blind arches, it is passed with a double cornice section. The body is divided into two with a double cornice. There is no ornament on the body, which has a window opening to the east in the lower part. The balcony wall was built with stone blocks. The upper parts of the minaret section with a door opening to the southwest are plain. The minaret, which is covered with an octagonal pyramid spire, has a crescent-tipped end ornament. This minaret resembles the minaret of the Şerefiye Mosque without ornaments. 


\subsection{Kalealtı (Aşă̆ı Kale) Mosque and Minaret}

Kalealtı (Aşağı kale) Mosque is located in the southwest of Bitlis Castle, next to the Kömüs stream. There is no inscription about its construction or repair in the mosque, which can also be classified as a neighborhood mosque. Arık (1971) [44] states that it is a 17,18th century structure typologically. The northwest corner and southeast part of this historical building, which has a square plan, were beveled due to the building it was built next to and the road. A lower section constructed at a different period than the main building was added to the entrance door of the sanctuary in the eastern part of the mosque [44]. The minaret of the mosque is not visible from time to time in old photographs. Today, in the southern part of the annex building, a minaret has a square prism-shaped pulpit built adjacent to the sanctuary wall. The minaret, which does not contain any ornamental elements, is transitioned from a cylindrical body to a stone-walled balcony with a fivestepped stone row. The cylindrical upper part of the minaret has a door opening to the south. A crescent-tipped end ornament is placed on the spire wrapped by lead sheets, which is uncommon in Bitlis [44,46].

\section{6. Şerefiye Külliye and Minaret}

The Şerefiye Külliye (complex of buildings) was built where the Kömüs (Hüsrev) and Rabat (Sapkor Suyu) Streams merged to form the Bitlis Stream. The mosque, minaret, imaret (the public soup kitchen), cupola, madrasah, and arasta (bazaar) were built on the west side of the streams, and the hammam was built on the east side. The connection between the Külliye is provided by the Şerefiye I Bridge on the Kömüs Stream and the Şerefiye II Bridge on the Rabat Stream. There is a mosque in the south of Külliye, the entrance gap, a cupola in the southeast, an imaret in the north, and a minaret in the northeast. In the eastern part of the külliye, there is a courtyard where the Kömüs stream is located. This section is entered through a portal opened from the south. There is an inscription on its portal states that it was built by Şeref Beg in 1528-1529. The door opens to a gap and there is the south window of the cupola. The left side opens to the portico of the mosque. Şerefiye Mosque is the only mosque in the city center with a portico place. The cupola, which was built by Emir Şemseddin in 1533, is the continuation of this section. There is a burial ground in the section between the cupola and the minaret. The imaret in the northern section was built at the same time as the mosque, and the northeast section was destroyed because of the overflow of the Kömüs stream. At the end of the imaret top cover of the square prism pulpit, there is an ornament element between the double cornices. In the south part, a panel with the inscription basmala in Kufic calligraphy was placed under the cornice. There is the entrance door of the minaret in the western part. Passing from square prism to octagonal transition segment is provided with triangulations. There are eight blind arches in the transition segment and, on the walls on the inner surface of these, panels with floral ornaments and the Kufic inscriptions are placed. In the transition to the cylindrical body with blind arches, it is passed with Kufic calligraphy inscribed ar the double cornice section. The body is divided into two by a plain double cornice. There are drop motif decorations in the lower part. The decorations in the section that passes to the balcony are made of limestone. The metal railing balcony was rebuilt with stone blocks during recent restoration works. The cylindrical upper part of the minaret section with a door opening to the southwest is plain. The minaret, which is covered with an octagonal pyramid spire, has an end ornament with a single-stage metal knob [44].

\section{Results}

\subsection{The Observed Damages in the Minarets}

Observational analyzes were made to reveal the current structural situation for each minaret. With these analyzes, information is given about the damages that occur in the minarets today. In short, before proceeding to the detailed structural analysis processes, structural analyses based on observation were made in order to provide information about the current status of Five Minarets. The purpose of this analysis is to reveal the 
current state of the building as well as to provide information about the damage and deformations that occur in the structure. Minarets have survived to the present day with protection and interventions by the relevant public institutions and organizations. However, partial damage occurred due to the high-temperature differences in the city and excessive precipitation. Bitlis Stone, with its local name, was used in all of the minarets. The stones obtained from the quarries in Bitlis were used in minarets after being subjected to the cutting process. One of the general features of Bitlis stone is discoloration and color change over time with the effects of natural conditions. Discoloration and color change were partially observed in almost all minarets studied. The Bitlis city, where the minarets are located, is one of the city centers with the highest snowfall in Turkey. Some of the minarets, which were examined due to excessive precipitation, have calcifications in places due to water effects. Some of the stones used in the building have occasional rupture and damage. It has been observed that there are almost no consolidation effects over time since the soil properties are good in the investigated structures. Although vegetative formations were noticeable in different parts of the minarets, they did not cause great damage to the minarets. It is seen that maintenance and restoration were conducted over time in all Five Minarets. Conducting such maintenance and restoration over time is an important step towards prolonging the life of the buildings and preserving the originality of the buildings. In addition, the bullet traces of the occupation forces during the years of occupation are also clearly visible. Neither random renovation nor restoration were made to the buildings. The images of the damages and deformations observed in Five Minarets are shown in Figure 4.

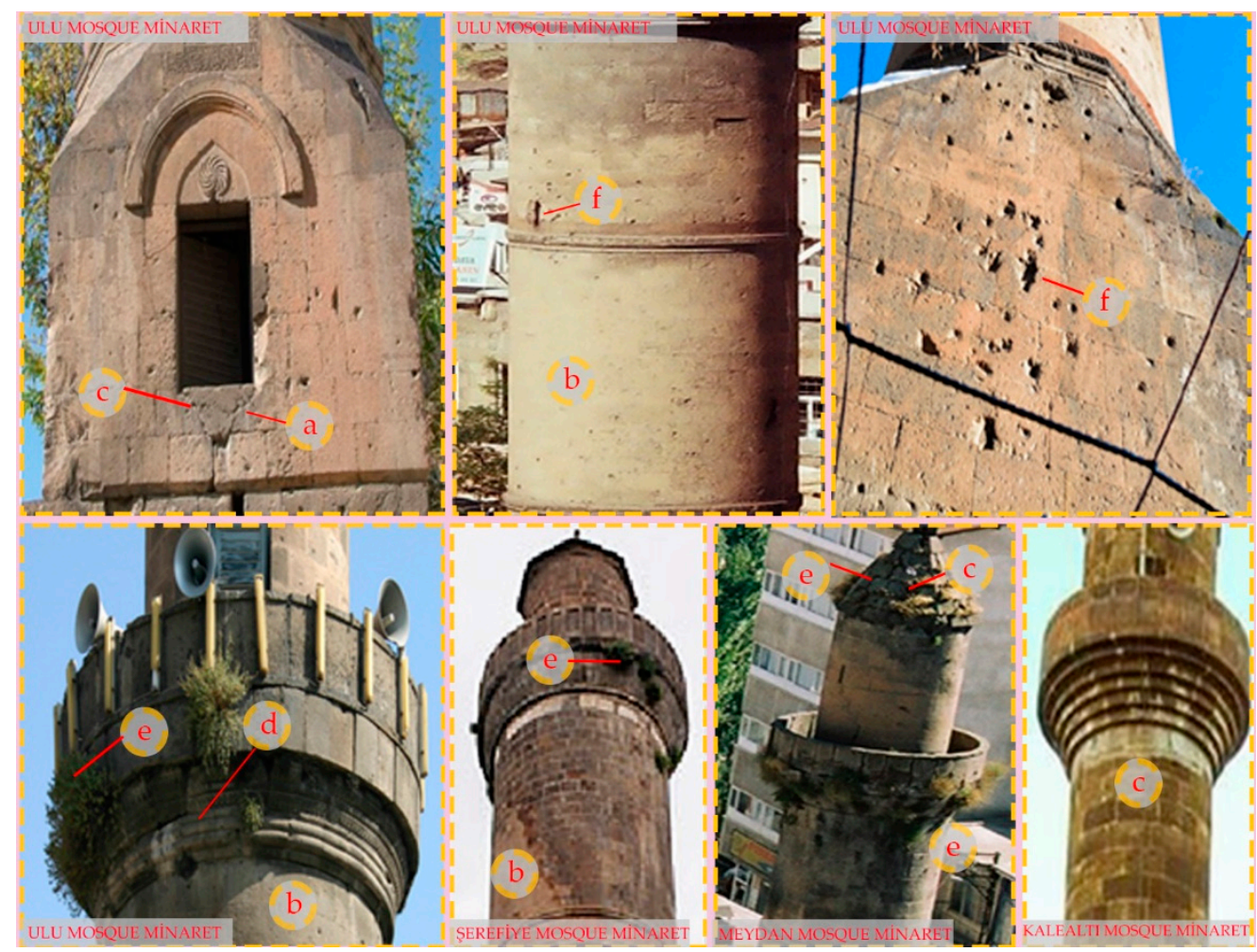

Figure 4. Damages observed in Five Minarets: a. high temperature difference; b. discoloration and color change; c. water effects; $d$. rupture damage; e. vegetation and f. bullet traces.

\subsection{The Determination of the Bitlis Stone Properties Used in Minarets}

It has been considered as a single type of the material, which is locally called Bitlis Stone, and is used in all the minarets considered in the study. Modulus of elasticity (E), Poisson ratio, and the weight per unit volume $(\gamma)$ values for Bitlis stone was taken as a single value for all minarets. While determining these values, the unit volume and the specific weight values were taken directly from the study by Işık et al. (2020) [50]. For the 
other two properties, the results were obtained by using the nondestructive test method. The propagation changes of the ultrasonic pulse velocity (UPV) wave are analyzed and applied without causing any deterioration in the material in the UPV method. This method, which enables the investigation of material homogeneity, can be considered an important method in the evaluation of concrete or natural stone structures [51]. In this method, an idea of the strength of the specimen is obtained based on the propagation speed of ultrasonic sound waves at certain frequencies in the specimen. Sound waves give an idea of cracks in the sample. An ultrasonic pulse is applied to one side of the sample with an ultrasonic pulse velocity tester, and pressure waves (P waves) are generated and recorded from the other side of the specimen. The ultrasonic pulse velocity tester measures the time taken by the pulse to proceed through the specimen. UPV equipment consists of a receiver, a transmitter, and a digital display [52]. The propagation times of the waves read from the device display were divided by the size of the specimen, and the propagation rates were determined for each sample. UPV test was applied to cube specimens of $15 \mathrm{~cm} \times 15 \mathrm{~cm} \times 15 \mathrm{~cm}$. The results obtained for the specimens are shown in Table 1.

Table 1. Test results of Bitlis stone.

\begin{tabular}{|c|c|c|c|c|c|c|c|c|}
\hline \multirow{2}{*}{$\begin{array}{l}\text { Specimen } \\
\text { Number }\end{array}$} & \multicolumn{2}{|c|}{ UPV (m/s) } & \multicolumn{2}{|c|}{$\mathrm{V}_{\mathrm{s}}(\mathrm{m} / \mathrm{s})$} & \multicolumn{2}{|c|}{ Poisson } & \multirow{2}{*}{\multicolumn{2}{|c|}{$\frac{\text { Modulus of Elasticity }}{\mathrm{kN} / \mathrm{m}^{2}}$}} \\
\hline & Direction 2 & Direction 3 & Direction 2 & Direction 3 & Direction 2 & Direction 3 & & \\
\hline 1 & $1574.5 \pm 93.9$ & $1804.5 \pm 57.5$ & $1032.9 \pm 62.33$ & $1185.557 \pm 38.17$ & $0.214295 \pm 0.002$ & $0.2085 \pm 0.001$ & $3755487 \pm 4.77$ & $4924239 \pm 4.13$ \\
\hline 2 & $1751.0 \pm 22.24$ & $1805.5 \pm 13.6$ & $1150.4 \pm 14.1$ & $1184.95 \pm 8.63$ & $0.208497 \pm 0.001$ & $0.2125 \pm 0.001$ & $4604603 \pm 1.21$ & $4901648 \pm 1.05$ \\
\hline 3 & $1543.25 \pm 58.55$ & $1687.5 \pm 36.06$ & $1009.3 \pm 39.2$ & $1105.313 \pm 24$ & $0.226122 \pm 0.002$ & $0.2202 \pm 0.001$ & $3570909 \pm 2.82$ & $4261941 \pm 2.44$ \\
\hline 4 & $1340.0 \pm 44.6$ & $1449.25 \pm 27.31$ & $875.02 \pm 29.72$ & $947.8095 \pm 18.19$ & $0.232153 \pm 0.002$ & $0.2261 \pm 0.001$ & $2791537 \pm 1.91$ & $3259257 \pm 1.65$ \\
\hline 5 & $1573.75 \pm 41.84$ & $1676.25 \pm 25.62$ & $1024.5 \pm 27.92$ & $1092.915 \pm 17.1$ & $0.244454 \pm 0.002$ & $0.2383 \pm 0.001$ & $3786705 \pm 2.05$ & $4287804 \pm 1.77$ \\
\hline 6 & $1608.0 \pm 6.94$ & $1625.00 \pm 4.25$ & $1058.1 \pm 5.23$ & $1070.875 \pm 3.2$ & $0.202775 \pm 0.002$ & $0.1971 \pm 0.001$ & $3930450 \pm 3.14$ & $4007304 \pm 2.72$ \\
\hline
\end{tabular}

According to the fracture test performed on cube specimens of $15 \times 15 \times 15 \mathrm{~cm}$ dimensions taken from natural stones known as Bitlis ignimbrites and used as building stones and the elastic property examinations obtained separately in two directions, the following results were obtained:

- Specimen 1 has the highest fracture load $(179.5 \mathrm{kN})$. The weight per unit volume was calculated as $14.2 \mathrm{kN} / \mathrm{m}^{3}$, average modulus of elasticity $4.34 \times 10^{6}\left(\mathrm{kN} / \mathrm{m}^{2}\right)$, average Poisson ratio 0.21 , and average shear modulus $1.79 \times 10^{6}\left(\mathrm{kN} / \mathrm{m}^{2}\right)$;

- The fracture load of specimen 2 was obtained as $163.8 \mathrm{kN}$. The weight per unit volume was calculated as $14.12 \mathrm{kN} / \mathrm{m}^{3}$, average modulus of elasticity $4.75 \times 10^{6}\left(\mathrm{kN} / \mathrm{m}^{2}\right)$, average Poisson ratio 0.21 , and average shear modulus $1.96 \times 10^{6}\left(\mathrm{kN} / \mathrm{m}^{2}\right)$;

- The fracture load of specimen 3 was obtained as $146.4 \mathrm{kN}$. The weight per unit volume was calculated as $14.02 \mathrm{kN} / \mathrm{m}^{3}$, average modulus of elasticity $3.92 \times 10^{6}\left(\mathrm{kN} / \mathrm{m}^{2}\right)$, average Poisson ratio 0.22 , and average shear modulus $1.60 \times 10^{6}\left(\mathrm{kN} / \mathrm{m}^{2}\right)$;

- The fracture load of specimen 4 was determined as $153.2 \mathrm{kN}$. The weight per unit volume was calculated as $14.51 \mathrm{kN} / \mathrm{m}^{3}$, average modulus of elasticity $3.03 \times 10^{6}\left(\mathrm{kN} / \mathrm{m}^{2}\right)$, average Poisson ratio 0.23 , and average shear modulus $1.23 \times 10^{6}\left(\mathrm{kN} / \mathrm{m}^{2}\right)$;

- The fracture load of specimen 5 was obtained as $153.2 \mathrm{kN}$. The weight per unit volume was calculated as $14.22 \mathrm{kN} / \mathrm{m}^{3}$, average elastic modulus $4.04 \times 10^{6}\left(\mathrm{kN} / \mathrm{m}^{2}\right)$, average Poisson ratio 0.24 , and average shear modulus $1.63 \times 10^{6}\left(\mathrm{kN} / \mathrm{m}^{2}\right)$;

- The fracture load of specimen 6 was obtained as $153.2 \mathrm{kN}$. The unit volume weight was calculated as $14.32 \mathrm{kN} / \mathrm{m}^{3}$, average modulus of elasticity $3.97 \times 10^{6}\left(\mathrm{kN} / \mathrm{m}^{2}\right)$, average Poisson ratio 0.20 , and average shear modulus $1.65 \times 10^{6}\left(\mathrm{kN} / \mathrm{m}^{2}\right)$.

Ignimbrites may be of different compositions due to their formation and may change over short distances when an evaluation is made about the specimens in general. The weight per unit volume of the six specimens examined is very close to each other and does not show great compositional differences. Porosity values are also in the range of $25 \%-26 \%$, and it is understood that they do not have a significant difference in terms of their formation. However, strength properties show significant changes. Measurements of the specimens taken from both directions showed that there were different strength values in 
both directions. Although the specimens have similar physical properties, the main reason why they have different values in strength properties is considered to be meteorological conditions. Particularly, the small amount of cracking in the direction where the specimen is exposed to the natural environment may cause a decrease in material strength. However, in general terms, it has sufficient strength conditions as a building block. Using the average values of these results, the material properties that are the basis for structural analysis are shown in Table 2.

Table 2. Material properties considered for Bitlis stone used in minarets.

\begin{tabular}{ccccc}
\hline Material Type & $\begin{array}{c}\text { Modulus of } \\
\text { Elasticity }\left(\mathbf{k N} / \mathbf{m}^{\mathbf{2}}\right)\end{array}$ & $\begin{array}{c}\text { Specific Weight } \\
\left(\mathbf{k N} / \mathbf{m}^{\mathbf{3}}\right)\end{array}$ & $\begin{array}{c}\text { Weight per Unit } \\
\text { Volume }\left(\mathbf{t} / \mathbf{m}^{\mathbf{3}}\right)\end{array}$ & Poisson Ratio \\
\hline Bitlis Stone & 4006824 & 20 & 1.46 & 0.22 \\
\hline
\end{tabular}

Modelling of masonry walls is extremely important in the evaluation and design of historical and modern masonry structures. Masonry walls can be modelled using three different modelling techniques such as detailed micro-modelling, simplified micromodelling, and macro-modelling. These models can be seen in Figure 5.
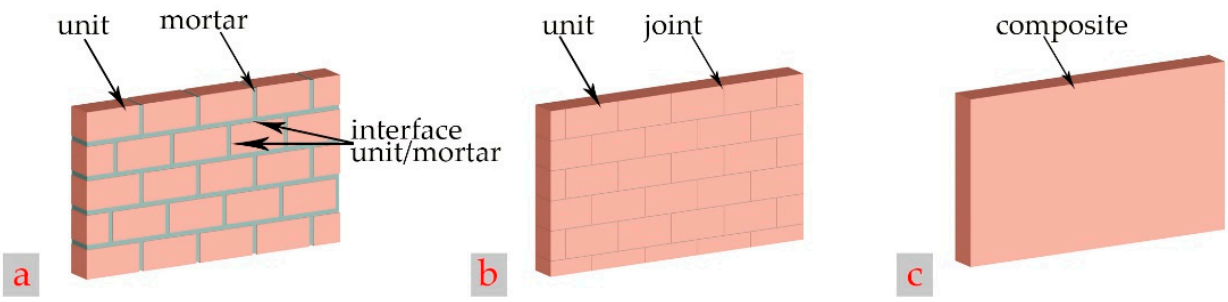

Figure 5. Modelling methods of masonry: (a) detailed micro modelling; (b) simplified micro modelling; and (c) Macro modelling.

In detailed micro-modelling, the mechanical properties of the masonry unit and the mortar forming the masonry wall are taken separately. In this approach, it is assumed that cracks will occur at the interfaces between the masonry unit and the mortar. In simplified micro-modelling, mass densification was made at each connection point consisting of a mortar and two masonry unit-mortar interfaces, and it was accepted that cracks that could occur in masonry could occur at the mean interface line, assuming the average interface. Findings differ slightly from detailed micro-modelling, as the Poisson ratio of the mortar is not taken into account here. However, this difference is so small that it can be neglected [53-55].

The macro modeling technique is one of the masonry structural modeling techniques and is widely used. While performing this type of modeling, analyses are carried out without making any distinction between the binding material (mortar, etc.) used in the building and the structural elements. In this modelling, the masonry unit and the properties of the mortar are homogenized and considered as a masonry composite material. The mechanical properties of this model are the values obtained as a result of the homogenization process. Macro modelling is more convenient in practice because it requires less memory and time. However, with macro modelling, stress distributions in masonry units and mortar can be obtained accurately [55-58] In this respect, structural masonry elements are considered composites, and an equivalent material model is used for all minarets models. Structural analyses were carried out for the Five Minarets in Bitlis using this macro-modeling technique. The mortar and Bitlis stone used in the minarets were considered as a single material. The sign criterion for the stress components of the elements used in the finite element model of the structure is shown in Figure 6, in accordance with the assumptions stipulated by the software [59] in which numerical modeling is made. 

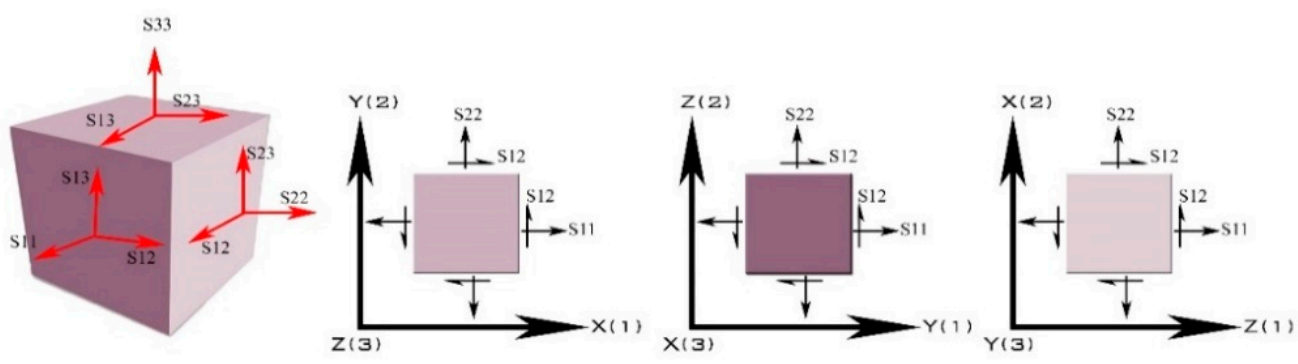

Figure 6. The sign criterion for the stress components.

As stated in Figure 6, S11 is vertical stress in (x) direction, S22 is vertical stress in (y) direction, S33 is vertical stress in (z) direction, and S12 = S21 constitute shear stresses in the $x-y$ plane. With TBEC-2018, which was updated in 2018 and entered into force on 1 January 2019 , the biggest change was the use of site-specific design spectra. Turkey Earthquake Maps Interactive Web Application has been developed to calculate design spectra and site-specific earthquake parameters. With the help of this application, horizontal and vertical design spectra can be obtained as well as earthquake parameters belonging to any desired geographical location. By using the coordinate values obtained for each minaret, design spectra and earthquake parameters were obtained with the help of this application. While obtaining these values, the design ground motion level DD-2 was chosen as the earthquake ground motion level. From the ground survey reports received from the relevant institutions, the $\mathrm{ZB}$ soil class was taken into account for all five minarets as the local soil class. As it can be seen from Table 3, the design spectra were obtained close to each other since the seismic parameters for the minarets are close to each other. The horizontal and vertical spectra obtained for the Ulu Mosque Minaret are shown in Figure 7 as an example. In these curves, the horizontal axis represents period values, while the vertical axes represent the horizontal and vertical elastic design spectral accelerations, respectively.

Table 3. The seismic parameters obtained for Five Minarets.

\begin{tabular}{|c|c|c|c|c|c|}
\hline Parameter & $\begin{array}{c}\text { Ulu } \\
\text { Mosque }\end{array}$ & $\begin{array}{l}\text { Gökmeydan } \\
\text { Mosque }\end{array}$ & $\begin{array}{l}\text { Meydan } \\
\text { Mosque }\end{array}$ & $\begin{array}{l}\text { Kalealtı } \\
\text { Mosque }\end{array}$ & $\begin{array}{l}\text { Şerefiye } \\
\text { Mosque }\end{array}$ \\
\hline Local soil classes & $\mathrm{ZB}$ & ZB & ZB & ZB & ZB \\
\hline Short period map spectral acceleration coefficient $\left(\mathrm{S}_{\mathrm{S}}\right)$ & 0.614 & 0.614 & 0.614 & 0.614 & 0.614 \\
\hline Map spectral acceleration coefficient for a $1.0 \mathrm{~s}$ period $\left(\mathrm{S}_{1}\right)$ & 0.172 & 0.172 & 0.172 & 0.172 & 0.172 \\
\hline Peak ground acceleration $(\mathrm{PGA})(\mathrm{g})$ & 0.260 & 0.260 & 0.260 & 0.260 & 0.260 \\
\hline Peak ground velocity (PGV) $(\mathrm{cm} / \mathrm{sn})$ & 15.081 & 15.123 & 15.082 & 15.084 & 15.079 \\
\hline Local soil effect coefficient for the short period region $\left(\mathrm{F}_{\mathrm{S}}\right)$ & 0.900 & 0.900 & 0.900 & 0.900 & 0.900 \\
\hline Local soil effect coefficient for $1.0 \mathrm{~s}$ period $\left(\mathrm{F}_{1}\right)$ & 0.800 & 0.800 & 0.800 & 0.800 & 0.800 \\
\hline $\begin{array}{l}\text { Short period design spectral acceleration coefficient } \\
\text { (unitless) }\left(\mathrm{S}_{\mathrm{DS}}\right)\end{array}$ & 0.553 & 0.553 & 0.553 & 0.553 & 0.553 \\
\hline $\begin{array}{c}\text { Design spectral acceleration coefficient for a } 1.0 \mathrm{~s} \text { period } \\
\text { (unitless) }\left(\mathrm{S}_{\mathrm{D} 1}\right)\end{array}$ & 0.138 & 0.138 & 0.138 & 0.138 & 0.138 \\
\hline $\mathrm{T}_{\mathrm{A}}$ & 0.050 & 0.050 & 0.050 & 0.050 & 0.050 \\
\hline $\mathrm{T}_{\mathrm{B}}$ & 0.249 & 0.249 & 0.249 & 0.249 & 0.249 \\
\hline $\mathrm{T}_{\mathrm{AD}}$ & 0.017 & 0.017 & 0.017 & 0.017 & 0.017 \\
\hline $\mathrm{T}_{\mathrm{BD}}$ & 0.083 & 0.083 & 0.083 & 0.083 & 0.083 \\
\hline
\end{tabular}

The earthquake parameters obtained for each minaret and used in structural analysis with the help of the Interactive Web Earthquake application are shown in Table 3.

While the dimensions of Five Minarets are shown in Figure 8, the three-dimensional models obtained from the software program are shown in Figure 9. 


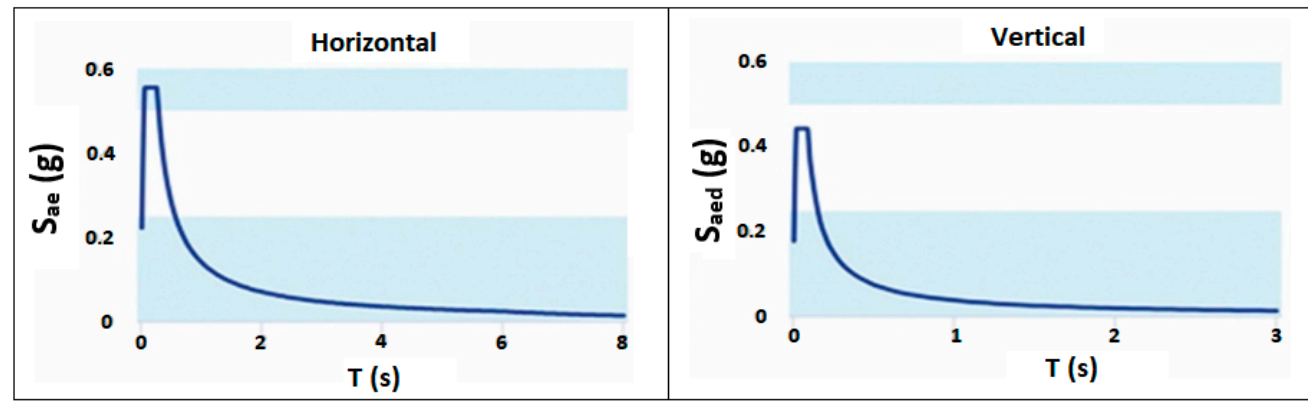

Figure 7. Horizontal and vertical design spectra obtained for the minaret of the Ulu Mosque.
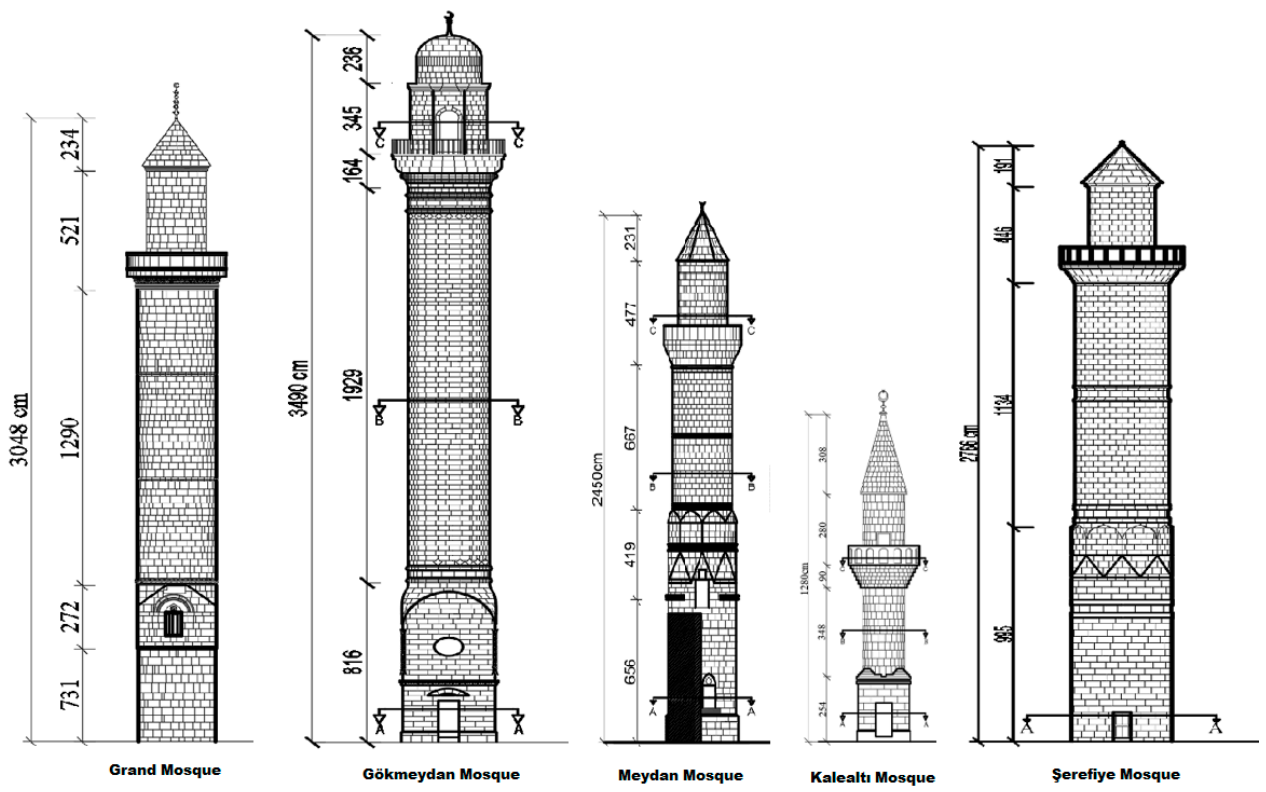

Figure 8. Dimensions of Five Minarets.

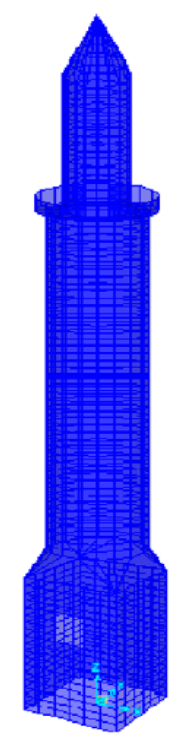

Grand Mosque

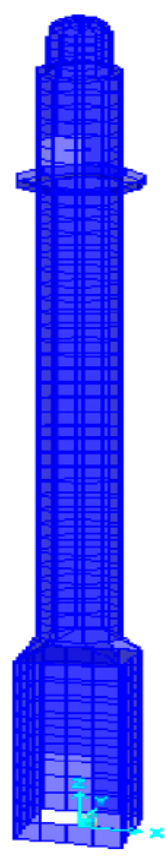

Gökmeydan Mosque

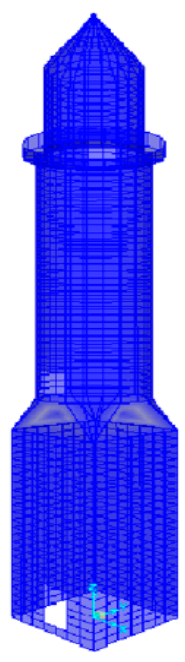

Meydan Mosque

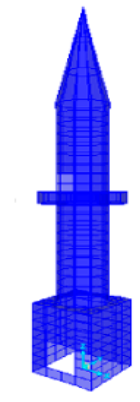

Kalealtı Mosque

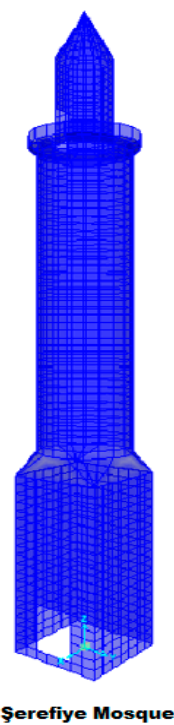

Figure 9. Three-dimensional models obtained from the software program of Five Minarets. 
In the structural analysis of the minarets, the finite element method, where the crosssection and material properties can be easily defined, was used. In finite element analysis, the geometry of the structure or structural elements is determined by a finite number of nodal points. The general structural properties of the minarets, the number of nodes, and the number of shell elements modelled in the software are shown in Table 4.

Table 4. Characteristics and structural model properties of Five Minarets.

\begin{tabular}{|c|c|c|c|c|c|c|}
\hline \multicolumn{2}{|c|}{ Minaret } & Ulu Mosque & Şerefiye Mosque & Meydan Mosque & Kalealtı Mosque & Gökmeydan Mosque \\
\hline \multicolumn{2}{|c|}{ Date of Construction } & $1492 / 93$ & 1533 & 17th century & 17-18th century & 1924 \\
\hline Material & $\begin{array}{l}\text { Stone } \\
\text { Brick } \\
\text { Earth }\end{array}$ & $\sqrt{ }$ & $\sqrt{ }$ & $\sqrt{ }$ & $\sqrt{ }$ & $\sqrt{ }$ \\
\hline Balcony & $\begin{array}{l}\text { Single } \\
\text { Double }\end{array}$ & $\sqrt{ }$ & $\sqrt{ }$ & $\sqrt{ }$ & $\sqrt{ }$ & $\sqrt{ }$ \\
\hline \multicolumn{2}{|c|}{ Height $(\mathrm{cm})$} & 3048 & 2766 & 2450 & 1280 & 3490 \\
\hline \multicolumn{2}{|c|}{ Location } & $\begin{array}{c}\text { Northwest of } \\
\text { courtyard } \\
\text { (at outside) }\end{array}$ & $\begin{array}{l}\text { Northeast of } \\
\text { courtyard } \\
\text { (at inside) }\end{array}$ & $\begin{array}{c}\text { Northwest of } \\
\text { mosque next } \\
\text { to portico }\end{array}$ & $\begin{array}{l}\text { East of mosque } \\
\text { at annex }\end{array}$ & Southwest of mosque \\
\hline \multirow{2}{*}{\multicolumn{2}{|c|}{$\begin{array}{l}\text { Footing Dimensions }(\mathrm{m}) \\
\text { Body Diameter }(\mathrm{m})\end{array}$}} & $3.10 \times 3.10$ & $3.0 \times 3.0$ & $3.75 \times 3.75$ & $2.15 \times 2.15$ & $2.90 \times 2.90$ \\
\hline & & 3.1 & 2.7 & 3.1 & 1.8 & 2.6 \\
\hline \multicolumn{2}{|c|}{ Body wall thickness (m) } & 0.6 & 0.45 & 0.5 & 0.2 & 0.35 \\
\hline \multicolumn{2}{|c|}{ Height $(\mathrm{m})$} & 30.48 & 27.66 & 24.5 & 12.8 & 34.9 \\
\hline \multicolumn{2}{|c|}{ Number of nodes } & 6808 & 7096 & 7220 & 1558 & 2648 \\
\hline \multicolumn{2}{|c|}{ Number of Shell element } & 1710 & 1781 & 1812 & 393 & 666 \\
\hline
\end{tabular}

Modal analysis is a dynamic analysis method that enables the determination of free vibration periods, frequency values, mass participation rates, and mode shapes of the structure. In order to determine the dynamic properties of the minarets, primarily modal analyzes were carried out. In TBEC-2018, it was requested to be determined according to the rule that the mass participation rates in the $\mathrm{X}$ and $\mathrm{Y}$ directions should not be less than $95 \%$. In this case, modal analyses were carried out by considering the first 34 modes for the Ulu Mosque minaret; the first 24 modes for Gökmeydan mosque minaret; the first 44 modes for the Meydan Mosque minaret; the first 31 modes for the Kalealt1 mosque minaret; and the first 43 modes for the Şerefiye Mosque minaret. The values related to the mass participation rates, natural vibration periods, and effective modes obtained by considering the first five modes of Five Minarets as a result of the modal analysis are shown in Table 5. Torsion in all minarets occurred in the fifth mode.

The dead-load, live-load, and earthquake-load are taken into account for stress calculations. The software program according to material properties made dead load calculations. Horizontal and vertical elastic design spectra obtained from Turkey Earthquake Hazard Maps Interactive Web Applications were used as design spectra. For the earthquake load, load definition was made in three directions as EQx, EQy, and EQz. Structural analyses were performed for different load combinations by using these values. The load combinations envisaged in the TBEC-2018, which is currently used in Turkey, have been taken into account. Load combinations have been selected in accordance with the definition under the title of Combining Earthquake Effect with other Effects in TBEC-2018. Load combinations are defined by the constant load effect, live load effect, earthquake effects defined in perpendicular directions, and the vertical earthquake effect together with the load coefficients. The stress diagrams for S11 (vertical stress in the x-direction) obtained from different load combinations are shown in Figure 10. 

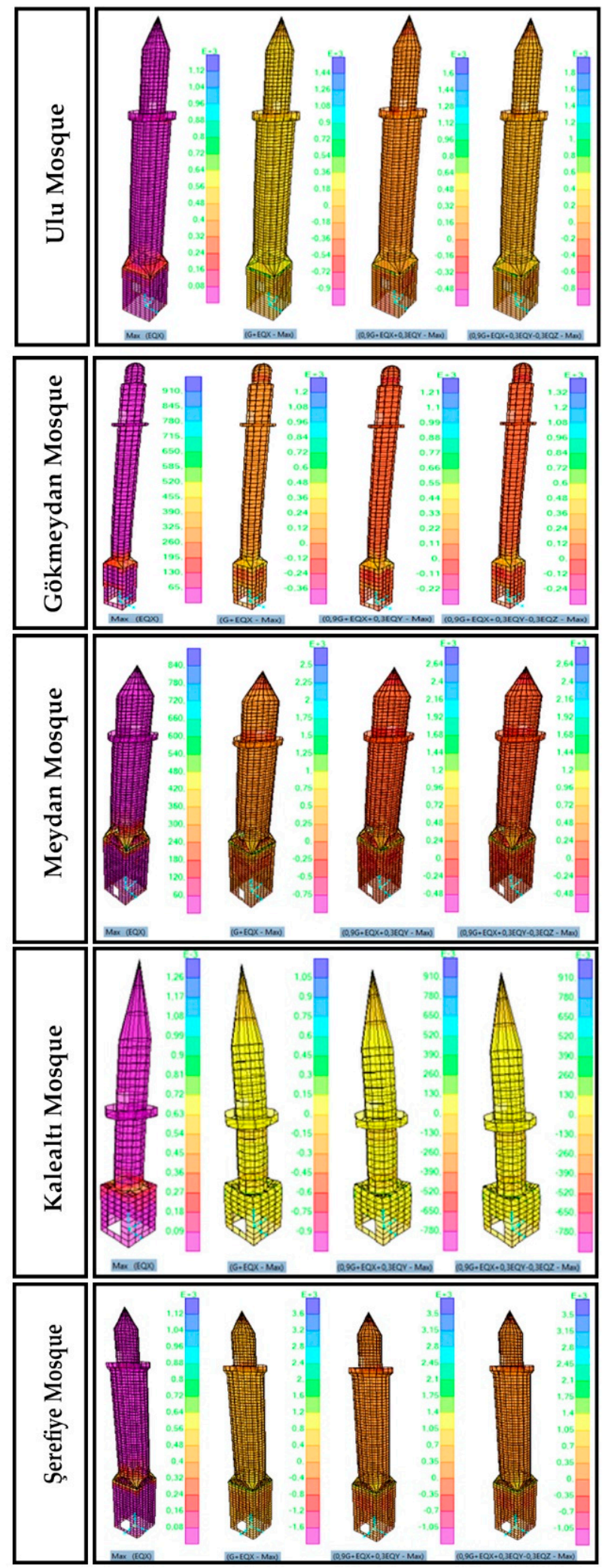

Figure 10. The maximum stress for Five Minarets (S11).

The maximum stress diagrams for the vertical stress in the y-direction (S22) obtained from different load combinations are shown in Figure 11. 

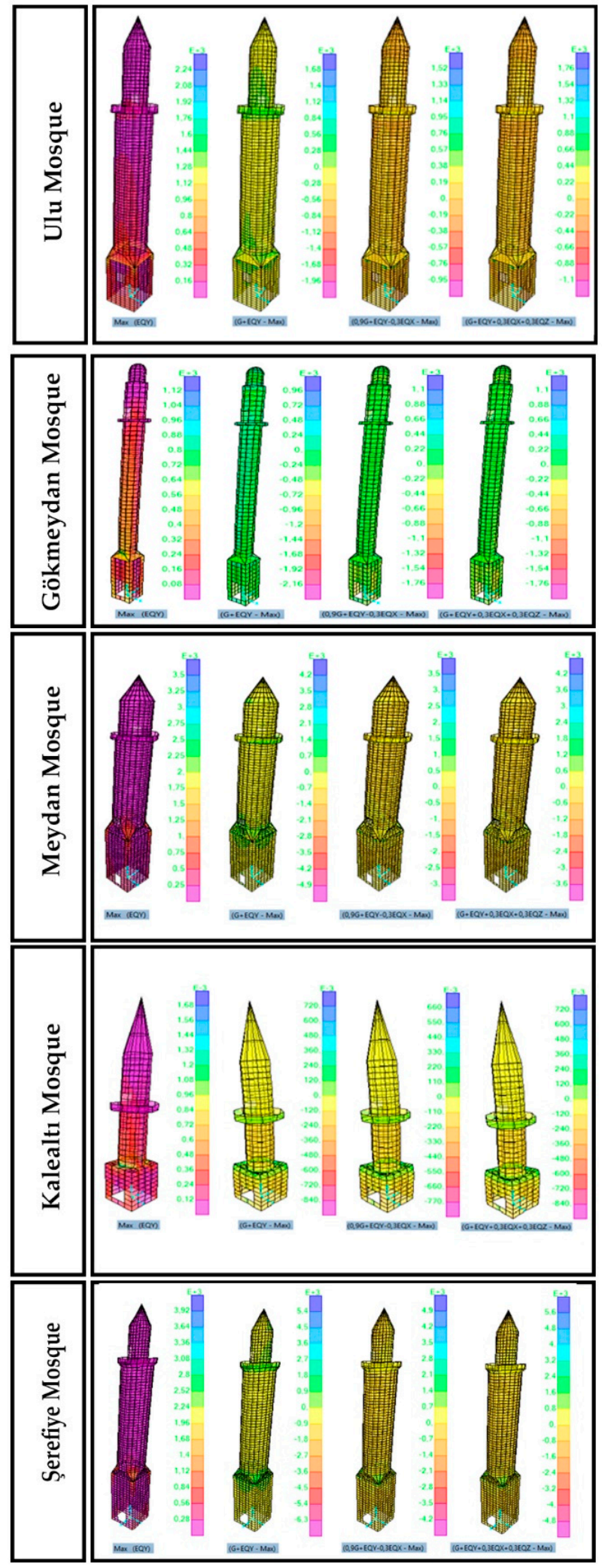

Figure 11. The maximum stress for Five Minarets (S22).

The diagrams of shear stress in the $\mathrm{x}$-y directions (S12) for five minarets under different load combinations are shown in Figure 12. 

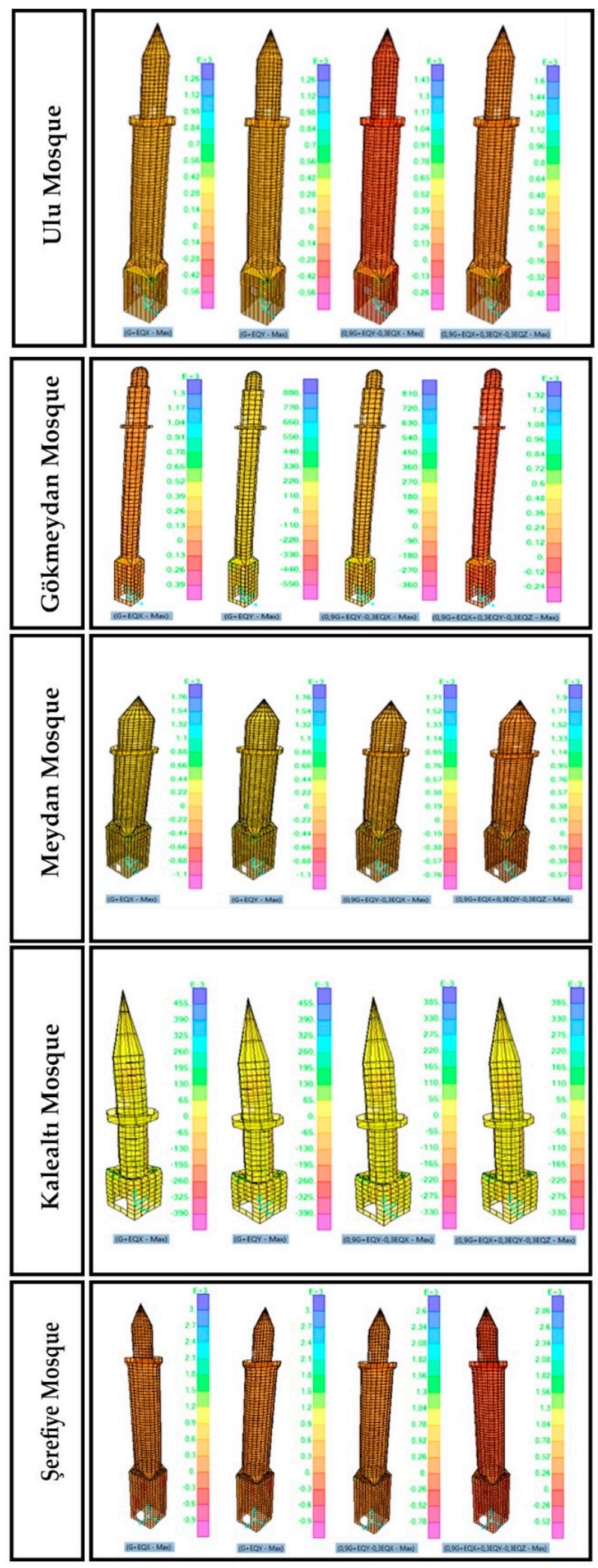

Figure 12. Maximum shear stress for Five Minarets (S12).

The comparison of the maximum tensile stresses for Five Minarets according to the results of the structural analysis is given in Table 6. 
Table 5. Modal analysis results of Five Minarets.

\begin{tabular}{|c|c|c|c|c|c|c|c|c|c|c|}
\hline Minaret & Mode & Period (s) & UX (m) & UY (m) & $\sum U X(\%)$ & $\sum U Y(\%)$ & $\mathrm{RX}(\mathrm{m})$ & $\mathrm{RY}(\mathrm{m})$ & $\sum R X(\%)$ & $\sum R Y(\%)$ \\
\hline \multirow{5}{*}{ Ulu } & 1 & 0.7104 & 0.01394 & 0.55769 & 1.39 & 55.77 & 0.4139 & 0.01027 & 41.39 & 1.03 \\
\hline & 2 & 0.7077 & 0.55858 & 0.01379 & 57.25 & 57.15 & 0.0104 & 0.41305 & 42.43 & 42.33 \\
\hline & 3 & 0.1450 & 0.07872 & 0.09275 & 65.13 & 66.42 & 0.0648 & 0.05621 & 48.91 & 47.95 \\
\hline & 4 & 0.1423 & 0.10062 & 0.07766 & 75.19 & 74.19 & 0.0555 & 0.07397 & 54.46 & 55.35 \\
\hline & 5 & 0.0991 & $3.88 \times 10^{-6}$ & $1.82 \times 10^{-5}$ & 75.19 & 74.19 & $1.8 \times 10^{-5}$ & $2.86 \times 10^{-7}$ & 54.46 & 55.35 \\
\hline \multirow{5}{*}{ Gökmeydan } & 1 & 1.7760 & 0.5089 & $6.00 \times 10^{-7}$ & 50.89 & 0.00 & $4.7 \times 10^{-7}$ & 0.49011 & 0.00 & 49.01 \\
\hline & 2 & 1.7410 & $4.89 \times 10^{-7}$ & 0.51229 & 50.89 & 51.23 & 0.4872 & $5.05 \times 10^{-7}$ & 48.72 & 49.01 \\
\hline & 3 & 0.3126 & 0.00581 & 0.21057 & 51.47 & 72.29 & 0.0925 & 0.00258 & 57.97 & 49.27 \\
\hline & 4 & 0.3103 & 0.22133 & 0.00575 & 73.60 & 72.86 & 0.0026 & 0.1001 & 58.23 & 59.28 \\
\hline & 5 & 0.1486 & 0.04561 & 0.00032 & 78.16 & 72.89 & 0.0003 & 0.05404 & 58.25 & 64.68 \\
\hline \multirow{5}{*}{ Meydan } & 1 & 0.6206 & 0.01356 & 0.53314 & 1.36 & 53.31 & 0.4317 & 0.01086 & 43.17 & 1.09 \\
\hline & 2 & 0.6135 & 0.53401 & 0.01338 & 54.76 & 54.65 & 0.011 & 0.43069 & 44.27 & 44.16 \\
\hline & 3 & 0.1201 & 0.2624 & 0.00205 & 81.00 & 54.86 & 0.0014 & 0.17858 & 44.40 & 62.01 \\
\hline & 4 & 0.1186 & 0.00214 & 0.2621 & 81.21 & 81.07 & 0.1711 & 0.00139 & 61.51 & 62.15 \\
\hline & 5 & 0.1054 & 0.00829 & $3.85 \times 10^{-5}$ & 82.04 & 81.07 & $2.4 \times 10^{-5}$ & 0.00433 & 61.52 & 62.58 \\
\hline \multirow{5}{*}{ Kalealtı } & 1 & 0.2861 & 0.00246 & 0.49748 & 0.25 & 49.75 & 0.4953 & 0.00252 & 49.53 & 0.25 \\
\hline & 2 & 0.2807 & 0.48622 & 0.00251 & 48.87 & 50.00 & 0.0025 & 0.49927 & 49.78 & 50.18 \\
\hline & 3 & 0.0658 & 0.24789 & $6.76 \times 10^{-6}$ & 73.66 & 50.00 & $8.0 \times 10^{-7}$ & 0.08725 & 49.78 & 58.90 \\
\hline & 4 & 0.0603 & $3.99 \times 10^{-6}$ & 0.22776 & 73.66 & 72.78 & 0.0926 & $1.37 \times 10^{-7}$ & 59.04 & 58.90 \\
\hline & 5 & 0.0490 & $4.80 \times 10^{-5}$ & 0.00033 & 73.66 & 72.81 & 0.0003 & 0.00024 & 59.07 & 58.93 \\
\hline \multirow{5}{*}{ Şerefiye } & 1 & 0.7953 & 0.53912 & 0.01179 & 53.91 & 1.18 & 0.0096 & 0.43307 & 0.96 & 43.31 \\
\hline & 2 & 0.7824 & 0.01191 & 0.53782 & 55.10 & 54.96 & 0.4332 & 0.0095 & 44.28 & 44.26 \\
\hline & 3 & 0.1449 & 0.00015 & 0.26134 & 55.12 & 81.10 & 0.1848 & $9.16 \times 10^{-5}$ & 62.76 & 44.27 \\
\hline & 4 & 0.1400 & 0.24586 & 0.0002 & 79.70 & 81.12 & 0.0002 & 0.16751 & 62.78 & 61.02 \\
\hline & 5 & 0.1160 & $8.23 \times 10^{-6}$ & 0.00301 & 79.71 & 81.42 & 0.0007 & $6.39 \times 10^{-6}$ & 62.85 & 61.02 \\
\hline
\end{tabular}

Table 6. Comparison of the maximum tensile stresses obtained for Five Minarets.

\begin{tabular}{cccc}
\hline Minaret & Load Combination & S11 (MPa) & S22 (MPa) \\
\hline Ulu Mosque & 0.9G + EQX + 0.3EQY - 0.3EQZ & 1.992 & 1.992 \\
Gökmeydan Mosque & G + EQX & 0.928 & 1.286 \\
Meydan Mosque & 0.9G + EQY - 0.3EQX & 2.817 & 4.229 \\
Kalealtı Mosque & 1.4G & 1.467 & 1.102 \\
Şerefiye Mosque & G + EQY + 0.3EQX + 0.3EQZ & 3.575 & 5.761 \\
\hline
\end{tabular}

The comparison of the maximum compressive stresses according to the analysis results for Five Minarets is given in Table 7.

Table 7. Maximum compressive stresses obtained for Five Minarets.

\begin{tabular}{cccc}
\hline Minaret & Load Combination & S11 (MPa) & S22 (MPa) \\
\hline Ulu Mosque & 0.9G + EQX + 0.3EQY - 0.3EQZ & 2.953 & 8.859 \\
Gökmeydan Mosque & G + EQX & 2.268 & 4.901 \\
Meydan Mosque & $0.9 \mathrm{G}+$ EQY - 0.3EQX & 2.517 & 12.099 \\
Kalealtı Mosque & $1.4 \mathrm{G}$ & 0.967 & 1.280 \\
Şerefiye Mosque & $\mathrm{G}+\mathrm{EQY}+0.3 \mathrm{EQX}+0.3 \mathrm{EQZ}$ & 4.062 & 14.460 \\
\hline
\end{tabular}

The comparison of the maximum shear stress values obtained from the structural analyzes for Five Minarets is given in Table 8.

Table 8. Comparison of the maximum shear stresses obtained for Five Minarets.

\begin{tabular}{ccc}
\hline Minaret & Load Combination & S12 (MPa) \\
\hline Ulu Mosque & $0.9 \mathrm{G}+\mathrm{EQX}+0.3 \mathrm{EQY}-0.3 \mathrm{EQZ}$ & 1.652 \\
Gökmeydan Mosque & $\mathrm{G}+\mathrm{EQX}$ & 1.327 \\
Meydan Mosque & $\mathrm{G}+\mathrm{EQY}+0.3 \mathrm{EQX}+0.3 \mathrm{EQZ}$ & 1.793 \\
Kalealtı Mosque & $1.4 \mathrm{G}$ & 0.507 \\
Şerefiye Mosque & $\mathrm{G}+\mathrm{EQY}+0.3 \mathrm{EQX}+0.3 \mathrm{EQZ}$ & 3.034 \\
\hline
\end{tabular}


According to the analysis results of Five Minarets, the maximum displacement of connection elements in both negative and positive $\mathrm{Ux}\left(\mathrm{U}_{1}\right)$ directions is given in Table 9.

Table 9. Maximum displacements of Five Minarets in Ux direction.

\begin{tabular}{cccc}
\hline Minaret & Load Combination & Type & $\mathbf{U}_{\mathbf{1}}(\mathbf{m m})$ \\
\hline Ulu Mosque & $0.9 \mathrm{G}+$ EQX + 0.3EQY $-0.3 \mathrm{EQZ}$ & Negative & 17.66536 \\
Gökmeydan Mosque & $\mathrm{G}+\mathrm{EQX}$ & Positive & 44.45398 \\
Meydan Mosque & $0.9 \mathrm{G}+\mathrm{EQX}+$ 0.3EQY $-0.3 \mathrm{EQZ}$ & Positive & 14.28112 \\
Kalealtı Mosque & $\mathrm{G}+\mathrm{EQX}$ & Negative & 0.13602 \\
Şerefiye Mosque & $0.9 \mathrm{G}+\mathrm{EQX}+0.3 \mathrm{EQY}-0.3 \mathrm{EQZ}$ & Positive & 19.88931 \\
\hline
\end{tabular}

According to the analysis results of Five Minarets, the maximum displacement of connection elements in both negative and positive $\mathrm{Uy}\left(\mathrm{U}_{2}\right)$ directions is given in Table 10.

Table 10. Maximum displacements of Five Minarets in $\mathrm{U}_{\mathrm{y}}$ direction.

\begin{tabular}{cccc}
\hline Minaret & Load Combination & Type & $\mathbf{U}_{\mathbf{2}}(\mathbf{m m})$ \\
\hline Ulu Mosque & G + EQY + 0.3EQX + 0.3EQZ & Negative & -17.93548 \\
Gökmeydan Mosque & G + EQY + 0.3EQX + 0.3EQZ & Negative & -40.81252 \\
Meydan Mosque & G + EQY + 0.3EQX + 0.3EQZ & Negative & -14.92157 \\
Kalealtı Mosque & G + EQY + 0.3EQX + 0.3EQZ & Negative & -0.23223 \\
Şerefiye Mosque & G + EQY + 0.3EQX + 0.3EQZ & Positive & 19.13056 \\
\hline
\end{tabular}

According to the analysis results of Five Minarets, the maximum displacement of connection elements in both negative and positive $\mathrm{Uz}\left(\mathrm{U}_{3}\right)$ directions is given in Table 11.

Table 11. Maximum displacements of Five Minarets in $U_{Z}$ direction.

\begin{tabular}{cclc}
\hline Minaret & Load Combination & Type & $\mathbf{U}_{\mathbf{3}}(\mathbf{m m})$ \\
\hline Ulu Mosque & 0.9G + EQX+0.3EQY - 0.3EQZ & Negative & -3.72910 \\
Gökmeydan Mosque & G + EQY + 0.3EQX + 0.3EQZ & Negative & -6.17395 \\
Meydan Mosque & G + EQY + 0.3EQX + 0.3EQZ & Negative & -4.44064 \\
Kalealt Mosque & G + EQY + 0.3EQX + 0.3EQZ & Negative & -0.39179 \\
Şerefiye Mosque & G + EQY + 0.3EQX + 0.3EQZ & Negative & -5.48402 \\
\hline
\end{tabular}

The highest period value was obtained for the Gökmeydan mosque minaret, which is the highest minaret, while the lowest period value was obtained for the Kalealtı mosque minaret. The variation of height directly affected the period values. The highest tensile stress values were obtained for the minaret of the Şerefiye Mosque, while the lowest values were obtained for the minaret of the Gökmeydan Mosque. The differences in the structural dimensions affected the tensile stresses. The highest values in terms of compressive stresses were obtained for the minaret of the Şerefiye Mosque, while the lowest values were obtained for the minaret of the Kalealtı Mosque. The highest shear stresses occurred in the minaret of the Şerefiye mosque, while the lowest shear stresses occurred in the minaret of the Kalealtı mosque. The largest displacements were obtained for the Gökmeydan mosque minaret, which is the highest minaret, while the smallest displacement values were obtained for the Kalealtı mosque minaret, which is the lowest one. All values obtained are considerably smaller than the minimum compression, tensile, and shear stress values in TS EN 1467 [60], which is used for natural stones and raw blocks in Turkey and includes natural stone properties. Accordingly, the minimum safe compressive stress is $34 \mathrm{MPa}$ [60]. Therefore, the values found in all of the minarets were obtained below this value. In addition, the minimum tensile strength in bending for blasted stones can be taken as $8 \mathrm{MPa}$ [61] For stone walls built in masonry, the safe shear stress $\left(\tau_{\mathrm{s}}\right)$ can be calculated by Equation (1). 


$$
\tau_{\mathrm{s}}=0.10+0.5 \sigma
$$

Here, $\sigma$ indicates the compressive strength of the material. The compressive strength value, which was calculated as $34 \mathrm{MPa}$ above, was substituted in Equation (1), and the safe shear stress value was calculated as $17 \mathrm{MPa}$. The maximum compressive, shear, and tensile stresses obtained from the analyses show thag these stresses can be safe to be carried by the structure. This result is in accordance with the fact that the structure survived in the process.

\section{Conclusions}

In the Bitlis stones, which formed the minarets under the influence of natural conditions, partial mass loss, rupture, and wear were observed over time. It has been surveyed that the vegetative cell formations formed on the minarets over time damaged the stones and the joining elements that formed the minaret. In some minarets, traces of moisture were observed, partly due to the harmful effects of water and the stone's characteristics. Many lead traces are still clearly observed on the minaret of the Ulu Mosque. Authorized institutions are proceeding to fix these damages and protect the structure from further damage in the future. Therefore, it was not possible to make a comparison between the damage conditions on the minarets and the results obtained.

In this study, structural analyses for Five Minarets, which are the significant cultural heritage of Bitlis province and have been the subject of songs, were carried out using observational and finite element methods. The fact that these minarets are exposed to many adverse effects over time makes these minarets' construction technologies and earthquake behavior more critical. Within the scope of this study, the seismic behavior of the minarets was determined by using the design spectrum given in the Turkish Building Earthquake Code (TBEC-2018), taking into account the different loading conditions for all five minarets. For this purpose, the mechanical properties of Bitlis stone used in minarets were determined for the first time within the scope of this thesis by using non-destructive test methods. Structural analysis of the minarets was carried out using the obtained values using the macro modeling method. S11, S22, and S12 stresses were founded for different loading cases of each minaret. Periods and mode shapes and data about minarets are given. The causes and results of the damage and destruction caused by the observational examinations made in the field are presented. Mainly, the maximum stress occurred in the transition zones of the minarets. It has been determined that the minaret can carry on these stresses. It expressed the engineering knowledge and experience when the minarets were built. In minarets, the effect of the cylindrical body and upper part of the minaret in the first mode is more significant than the pulpit. The common elements in the transition zones where cross-sectional changes occur in the minarets can be expressed as risky places. The fact that the elements that formed the pulpits have more rigidity indicates that the degree of damage will remain at lower values in this region. In this case, transition zones in minarets can be expressed as risky zones.

Bitlis stone, which is used in all of the minarets, is weak strength and has high porosity ratio, as well as the high-temperature difference in the city, the high and long-term snowfall causes fragmentation and partial rupture of these stones. In a city where the winter season is long, the freezing-thawing factor is one of the important reasons for decreasing the strength of the stone. Therefore, Bitlis stone, which is the main structural element of minarets, may lose its mechanical properties over time and affect its strength. In order to solve this problem, institutions /organizations related to minarets should observe the minarets structurally and ensure that the necessary engineering interventions are made in a timely. In this respect, the relevant public institutions and organizations have preserved the originality of the minarets by carrying out the necessary works and procedures. The continuity of such works and transactions is very important in order to transfer the minarets to the next generations. 
The fact that the structural dimensions such as total height, diameter, wall thickness, and pulpit dimensions of the minaret had different values for Five Minarets caused the analysis results to be different from each other. Therefore, compressive, tensile, shear stresses, period, and displacement values differed.

Five Minarets are in Bitlis city center, they are close to each other, and the design spectra obtained are close to each other because the local soil class has the same values. In future studies, the effects of these variables on the behavior of masonry minaret structures will be examined. In this subject, this paper can be used as a source. In the study, only macro modeling was considered while performing structural analyses for each minaret. The material properties of the elements that make up the minarets will be determined in future studies. In addition, the analysis in the time history analyzes using micro modeling technique will also contribute.

It is vital that the Five Minarets are the most important historical structures of Bitlis city and be transferred to the next generations. For this purpose, these minarets should be observed according to the structural monitoring system, and when necessary, their maintenance work should be perfomed correctly. It is recommended that the necessary applications be made by the relevant institutions and organizations at the point of inclusion of Five Minarets in the UNESCO World heritage. This and similar studies will make important contributions to make this process happen faster and on a scientific basis.

\begin{abstract}
Author Contributions: Conceptualization, E.I., F.A., and E.H.; methodology, M.G., E.I., E.A. and E.H.; software, M.G. and E.I.; validation, E.A., E.I., F.A. and E.H.; formal analysis, E.H.; investigation, E.I. and M.G.; resources, E.A., E.I., M.G. and E.H.; data curation, E.I. and M.G.; writing-original draft preparation, E.H. and E.A.; writing-review and editing, E.H., E.I. and F.A.; visualization, E.A.; supervision, E.H. and E.I.; project administration, E.I.; funding acquisition, E.H. All authors have read and agreed to the published version of the manuscript.
\end{abstract}

Funding: This research received no external funding.

Institutional Review Board Statement: Not applicable.

Informed Consent Statement: Not applicable.

Data Availability Statement: Most data are included in the manuscript.

Acknowledgments: This research was produced from master thesis of fifth author of the article. We acknowledge the support of the German Research Foundation (DFG) and the Bauhaus-Universität Weimar within the Open-Access Publishing Programme.

Conflicts of Interest: The authors declare no conflict of interest.

\title{
References
}

1. Hadzima-Nyarko, M.; Ademovic, N.; Pavic, G.; Sipos, T.K. Strengthening techniques for masonry structures of cultural heritage according to recent Croatian provisions. Earthq. Struct. 2018, 15, 473-485.

2. Isik, E.; Antep, B.; Buyuksarac, A.; Isik, M.F. Observation of behavior of the Ahlat Gravestones (TURKEY) at seismic risk and their recognition by QR code. Struct. Eng. Mech. 2019, 72, 643-652.

3. Pavić, G.; Hadzima-Nyarko, M.; Plaščak, I.; Pavić, S. Seismic vulnerability assessment of historical unreinforced masonry buildings in Osijek using capacity spectrum method. Acta Phys. Pol. A 2019, 135, 1138-1141. [CrossRef]

4. Bilgin, H. Typological classification of churches constructed during post-Byzantine period in Albania. Gazi Univ. J. Sci. Part B Art Humanit. Des. Plan. 2015, 3, 1-15.

5. Akan, A.E.; Başok, G.; Er, A.; Örmecioğlu, H.T.; Koçak, S.Z.; Cosgun, T.; Uzdil, O.; Sayin, B. Seismic evaluation of a renovated wooden hypostyle structure: A case study on a mosque designed with the combination of Asian and Byzantine styles in the Seljuk era (14th century AD). J. Build. Eng. 2021, 43, 103112. [CrossRef]

6. Karasin, I.B.; Isik, E. Protection of Ten-Eyed Bridge in Diyarbakır. Budownictwo i Architektura 2016, 15, 87-94. [CrossRef]

7. Hadzima-Nyarko, M.; Mišetić, V.; Morić, D. Seismic vulnerability assessment of an old historical masonry building in Osijek, Croatia, using Damage Index. J. Cult. Herit. 2017, 28, 140-150. [CrossRef]

8. Giordano, A.; Mele, E.; De Luca, A. Modelling of historical masonry structures: Comparison of different approaches through a case study. Eng. Struct. 2002, 24, 1057-1069. [CrossRef]

9. Işık, E.; Antep, B.; Büyüksaraç, A. Structural analysis and mapping of historical tombs in Ahlat District (Bitlis, Turkey). Jcr-E-GFOS 2019, 10, 22-35. [CrossRef] 
10. De Backer, L.; Janssens, A.; Steeman, M.; De Paepe, M. Evaluation of display conditions of the Ghent altarpiece at St. Bavo Cathedral. J. Cult. Herit. 2018, 29, 168-172. [CrossRef]

11. Ortega, J.; Vasconcelos, G.; Rodrigues, H.; Correia, M.; Lourenço, P.B. Traditional earthquake resistant techniques for vernacular architecture and local seismic cultures: A literature review. J. Cult. Herit. 2017, 27, 181-196. [CrossRef]

12. Cosgun, T.; Sayin, B.; Gunes, B.; Osman Avşar, A.; Şengün, R.; Gümüşdă̆, G. Rehabilitation of historical ruined castles based on field study and laboratory analyses: The case of Bigalı Castle in Turkey. Rev. Constr. 2020, 19, 52-67. [CrossRef]

13. Bilgin, H.; Ramadani, F. Numerical study to assess the structural behavior of the Bajrakli Mosque (Western Kosovo). Adv. Civ. Eng. 2021, 2021, 4620916. [CrossRef]

14. Formisano, A.; Milani, G. Seismic vulnerability analysis and retrofitting of the SS. Rosario church bell tower in Finale Emilia (Modena, Italy). Front. Built. Environ. 2019, 5, 70. [CrossRef]

15. Illampas, R.; Ioannou, I.; Lourenço, P.B. Seismic appraisal of heritage ruins: The case study of the St. Mary of Carmel church in Cyprus. Eng. Struct. 2020, 224, 111209. [CrossRef]

16. Hemeda, S. Geotechnical and geophysical investigation techniques in Ben Ezra Synagogue in Old Cairo area, Egypt. Herit. Sci. 2019, 7, 23. [CrossRef]

17. Carpinteri, A.; Lacidogna, G.; Manuello, A. The b-value analysis for the stability investigation of the ancient Athena Temple in Syracuse. Strain 2011, 47, e243-e253. [CrossRef]

18. Castellazzi, G.; Gentilini, C.; Nobile, L. Seismic vulnerability assessment of a historical church: Limit analysis and nonlinear finite element analysis. Adv. Civ. Eng. 2013, 2013, 517454. [CrossRef]

19. Karantoni, F.V.; Dimakopoulou, D. Displacement-based assessment of the Gazi Hasan Pasha mosque in Kos island (GR) under the 2017 M6. 6 earthquake and Eurocode 8, with proposals for upgrading. Bull. Earthq. Eng. 2021, 19, 1213-1230. [CrossRef]

20. Çaktı, E.; Saygıll, Ö.; Görk, S.; Zengin, E.; Oliveira, C.S.; Lemos, J.V. Earthquake behavior of the minaret of the Mihrimah Sultan mosque in Edirnekapı, İstanbul. Restorasyon Yıllı̆̆ı Dergisi 2013, 6, 33-40.

21. Işık, E.; Antep, B. Structural analysis of historical masonry minaret in Ahlat. BEU J. Sci. 2018, 7, 46-56.

22. TSDC-2007. Turkish Seismic Design Code; T.C. Resmi Gazete: Ankara, Turkey, 2007.

23. Kılıç, İ.; Bozdoğan, K.B.; Aydın, S.; Gök, S.G.; Gündoğan, S. Determination of dynamic behaviour of tower type structures: The case of Kırklareli Hizırbey Mosque minaret. J. Polytech. 2020, 23, 19-26.

24. TBEC. Turkish Building Earthquake Code; T.C. Resmi Gazete: Ankara, Turkey, 2018.

25. Ural, A.; Çelik, T. Dynamic analyses and seismic behavior of masonry minarets with single balcony. Aksaray J. Sci. Eng. 2018, 2, 13-27. [CrossRef]

26. Mutlu, Ö.; Şahin, A. Investigating the effect of modeling approaches on earthquake behavior of historical masonry Minarets-Bursa Grand Mosque case study. Sigma 2016, 7, 123-136.

27. Bayraktar, A.; Çalık, İ.; Türker, T. Structural dynamic identification of a restored historical masonry Sundura mosque and minaret using ambient vibration. Restorasyon Yıllı̆̆l 2013, 6, 53-62.

28. Günaydın, M. Experimental determination of the dynamic characteristics of a historical masonry minaret after repairing. GU J. Sci. Technol. 2018, 8, 381-395.

29. Çarhoğlu, A.I.; Usta, P.; Korkmaz, K.A. Seismic behaviour investigation of historical minaret structures: Hagia Sophia case. SDU Int. Technol. Sci. 2013, 5, 36-43.

30. Uğurlu, M.A.; Günaslan, S.E.; Karaşin, A. Modelling and structural analysis of the Four-legged minaret. DU J. Eng. 2017, 8, 413-422.

31. Oğuzmert, M. Dynamic Behavior of Masonry Minarets. Master's Thesis, Istanbul Technical University, İstanbul, Turkey, 2002.

32. Döven, M.S.; Serhatoğlu, C.; Kaplan, O.; Livaoğlu, R. Dynamic behaviour change of Kütahya Yeşil minaret with covered and open balcony architecture. Eskişehir Tech. Univ. J. Sci. Technol. B-Theor. Sci. 2018, 6, 192-203.

33. Gunes, B.; Cosgun, T.; Sayin, B.; Ceylan, O.; Mangir, A.; Gumusdag, G. Seismic assessment of a reconstructed historic masonry structure: A case study on the ruins of Bigali castle mosque built in the early 1800s. J. Build. Eng. 2021, 39, 102240. [CrossRef]

34. Ertek, E.; Fahjan, M.Y. Structural system of Ottoman minarets; classification, modelling and analysis. In Proceedings of the Sixth National Conference on Earthquake Engineering, İstanbul, Turkey, 16-20 October 2007; pp. 16-20.

35. Çalık, İ.; Bayraktar, A.; Türker, T. Simplified natural frequency formulas for historical masonry stone minarets based on experimental methods. In Proceedings of the Uluslararası Katılımlı 6. Tarihi Yapıların Korunması ve Güçlendirilmesi Sempozyumu, Trabzon, Turkey, 2-4 November 2007.

36. Yetkin, M.; Dedeoğlu, İ.Ö.; Calayır, Y. Investigation and assessment of damages in the minarets existing at Elazig after 24 January 2020 Sivrice earthquake. Firat Univ. J. Eng. Sci. 2021, 33, 379-389.

37. Kültür Portalı. Türkiye Kültür Portalı. Available online: https://www.kulturportali.gov.tr/ (accessed on 25 December 2021).

38. Bitlis İl Kültür ve Turizm Müdürlüğü. Available online: https:// bitlis.ktb.gov.tr/ (accessed on 20 December 2021).

39. Aslanapa, O. Anadolu'da ilk Türk Mimarisi: Başlangıcı ve Gelişmesi; Atatürk Kültür, Dil ve Tarih Yüks. Yayını: Ankara, Turkey, 1991.

40. Baş, G. Bitlis'teki Mimari Yapılarda Süsleme; Bitlis Valiliği Kültür Yayınları: Bitlis, Turkey, 2002.

41. Hasol, D. Encyclopedic Architecture Dictionary; Building Industry Center Publications: Istanbul, Turkey, 1998.

42. Güler, M.; Aktuğ, İ.K. 12th century Anatolian Turkish mosques. İtüdergisi/a 2006, 5, 83-90.

43. T.R. Directorate General of Foundations. Available online: https://www.vgm.gov.tr/home-page (accessed on 25 December 2021).

44. Arık, O. Bitlis Yapılarında Selçuklu Rönesansı; Selçuklu Tarih ve Medeniyeti Enstitüsü Yayını: Ankara, Turkye, 1971. 
45. Şen, K. Two important inscriptions belong to the Bitlis grand mosque and Bitlis castle. ASEAD 2018, 5, $147-156$.

46. Uluçam, A. Ortaçă̆ ve Sonrasında Van Gölü Çevresi Mimarlı̆̆ı-II-Bitlis; Kültür Bakanlığı Yayınları: Ankara, Turkey, 2002.

47. Aslanapa, O. Anadolu'da Türk sanatı Anadolu'da Büyük Selçuklulara Bağlanan Camiler; Atatürk Kültür Merkezi Yayinlari: Ankara, Turkey, 2007.

48. Ülkü, C.; Yeğin, M. Courtyard in 11-12 century mosques/The newly discovered courtyard in Bitlis Ulu Mosque. J. Soc. Sci. 2017, 17, 17-37.

49. Öztürk, Ş. Bitlis Merkez Meydan Camii. Vakıflar Dergisi 2004, 28, 157-171.

50. Işık, E.; Büyüksaraç, A.; Avşar, E.; Kuluöztürk, M.F.; Günay, M. Characteristics and properties of Bitlis ignimbrites and their environmental implications. Materiales de Construcción 2020, 70, 214. [CrossRef]

51. Lorenzi, A.; Tisbierek, F.T.; Silva, L.C.P. Ultrasonic pulse velocity análysis in concrete specimens. In Proceedings of the IV Conferencia Panamericana de END, Buenos Aires, Argentina, 22-26 October 2007.

52. Sharma, P.K.; Khandelwal, M.; Singh, T.N. A correlation between schmidt hammer rebound numbers with impact strength index, slake durability index and P-wave velocity. Int. J. Earth Sci. 2011, 100, 189-195. [CrossRef]

53. Lourenço, P.B. An Orthotropic Continuum Model for the Analysis of Masonry Structures; Delft University of Technology: Delft, The Netherlands, 1995; pp. 3-21.

54. Lee, J.S.; Pande, G.N.; Middleton, J.; Kralj, B. Numerical modelling of brick masonry panels subject to lateral loadings. Comput. Struct. 1996, 61, 735-745. [CrossRef]

55. Pande, G.N.; Liang, J.X.; Middleton, J. Equivalent elastic modul for unit masonry. Comput. Geotech. 1989, 8, 243-265. [CrossRef]

56. Laurenco, P.B.; Rots, J.G.; Blaauwendraad, J. Two approaches for the analysis of masonry structures: Micro and macro-modeling. Heron 1995, 40, 1995.

57. Pande, G.N.; Middleton, J.; Kralj, B. Computer METHODS in structural Masonry 4. In Proceedings of the Fourth International Symposium on Computer Methods in Structural Masonry, Florence, Italy, 3-5 September 2017.

58. Lourenço, P.B. Computations on historic masonry structures. Prog. Struct. Eng. Mater. 2002, 4, 301-319. [CrossRef]

59. CSI Computers and Structures. SAP2000: Integrated Software for Structural Analysis and Design Ver. 19; CSI: Berkeley, CA, USA, 2017.

60. TS EN 1467. Doğal Taş-Ham Bloklar-Özellikleri; Türk Standardı: Ankara, Turkey, 2012.

61. Kuruşcu, A.O. Non-Lineer Modeling of Masonry Walls and Foundations. Ph.D. Thesis, YTU Graduate School of Science and Technology, İstanbul, Turkey, 2012. 